From the forester's viewpoint much of this increase reflects that marginal land is inexorably reverting, or doing its best to revert, to forest. That is to say, much of the present $5 \frac{1}{2}$ million acres of occupied scrub, fern, and second growth land should De allowed to revert to forest. Not only is Nature clutching it back, but even if it were by some magic wand cleared of its present so-called "weed" vegetation, much of it is too steep or unstable or infertile under existing practice to be economically farmable as pasture land. The best use for such areas is forest, whether it be protection or production forest.

Appreciation of the risk of manuka blight upsetting Nature's efforts to reclothe both unoccupied depleted areas and small unstable and infertile occupied areas is a duty on the part of those who are spreading manuka blight. Some farmers have declared that they will have nothing to do with this liberation of a disease, but they seem to constitute a definite minority.

Dr. Currie, Vice-Chancellor of the University of New Zealand, recently said that when designing a course in Australia for ex-servicemen desiring to go on the land he divided the course into four sections:-

$$
\begin{aligned}
& \text { Farming as a business; } \\
& \text { Farming as a science; } \\
& \text { Farming as a practical art; } \\
& \text { Farming as a way of life. }
\end{aligned}
$$

The forester would appeal to the farmer to consider all these aspects of his calling as related to indiscriminate spreading of manuka blight. Farming as a business demands that manuka be exterminated from economically farmable, permanent pastures. All of us must surely be in agreement on that. I have been told that there are better ways of doing this than by employing the blight; farming as a science and a practical art should know whether this is so. At all events farming both as a way of life and as a science should be very concerned with permanence, with taking the long view, and with the public good.

\title{
Agriculturist's View
}

\section{J. HAMBLYN, Department of Agriculture, Palmerston North.}

THE agriculturist who has experience and knowledge of the problem of the control and eradication of red manuka (Leptospermum scoparium) on the farm lands of New Zealand, who knows and realises the menace this plant is to the farmers of the country, and who appreciates that despite the tremendous annual expenditure incurred by farmers in their efforts to keep ahead of its encroachment this plant is steadily gaining headway over increasing areas of grassland, welcomes, with the farmers most concerned, the advent of an agency such as the mealy bug Eriococcus which gives such definite promise of gaining at last that much desired cheap and effective control.

To appreciate fully this attitude of the farmer, the hill country man in particular, and of the agriculturist concerned especially with the future of the millions of acres of hill country, ever threatened by this pest, red manuka, it is necessary to know something of the economic importance of this plant to the farming community, and something of the everincreasing threat this plant is to the future of farming on vast areas of our more difficult farming lands. It is necessary also to know what the mealy bug can do in the way of eradication and control of manuka, and what happens while it does the job, under the varied conditions of 
soil, climate, and topography over which the battle with manuka is being carried on. It is necessary to realise above all that manuka, in so far as our farm lands are concerned, is the most widespread, insidious, aggressive weed we have, and on hill country, at least, the most persistent. Is it any wonder that to farmers the easy and wholesale eradication of this pest by an insect would be a very welcome blessing?

This paper on the subject of an agriculturist's views on manuka blight is based on some 30 years of experience of farms and farming up and down the North Island, and of some 7 years' close observation of the developments taking place since the introduction of the mealy bug to the southern half of the North Island in 1946. The writer is indebted in this regard to the numerous reports of observations and surveys made by field officers of the Department of Agriculture. Because of a more intimate knowledge of the southern half of the island gained during the past 18 years, the paper will deal mainly with conditions in the area covered by the land districts of Taranaki, Wellington, Hawke's Bay, and Poverty Bay.

THE SPREAD OF MANUKA

Red manuka to-day is looked on as a universal plant of the country; it is found almost everywhere; but research into the writings of early travellers and explorers up and down the country, including noted botanists and naturalists, shows that manuka had quite an insignificant place in the flora of the country they described. This includes such vast areas as the gumlands of the Auckland Province, which before the advent of diggers and fires were clothed with a varied association of plants in which manuka was not conspicuous, the pumice lands, described as a vista bracken fern and tutu, and the forest lands, with no mention at all of manuka except as a plant to be found here and there. Even the peat lands were practically devoid of manuka before fires destroyed the cover of rush and bracken fern.

The early colonists in their writings about the development of farm lands from forest, from bracken fern, or from native grasses make no mention of red manuka as a plant they had to deal with.

All this is not to say that manuka was not a universal plant or that it had played no part in the development of the flora as it was found by the settlers. It does indicate, however, that manuka has developed as an aggressive weed of farm lands aided over vast areas of long unoccupied country by continual burning. In the case of forest lands developed for farming by the felling and burning of the original bush cover, the reversion to bracken fern was the first major problem, but bracken fern, now controlled by cattle, has been succeeded by manuka as the original fertility has worn off. Almost anywhere that manuka grows, so will bracken fern, and of these 2 plants, there should be no doubt as to which is the better for soil conservation and the prevention of excessive water run-off. It is also a very debatable point as to whether bracken fern is not as satisfactory as a nursery for reafforestation. At least reafforestation appears to start much more quickly in bracken fern areas than it does where manuka has occupied the land.

\section{The Incidence of Manuka To-day}

A careful survey of the incidence of manuka as a weed of farmlands in the four land districts of Taranaki, Wellington, Hawke's Bay, and Poverty Bay has shown that of the 11 million acres of occupied land less than 3 million acres are at present free from manuka or the menace of manuka, while over some 7 million acres, including upwards of 6 million acres of hill country, manuka is widespread and on a great deal of the more fertile hill country is but recently coming in as small clumps and isolated plants. There are also some $1 \frac{1}{2}$ million acres of undeveloped land, part of it in forest but the major part reverted to manuka. 


\section{The Effort to Control Manuka}

It is recognised that by cultivation and topdressing regularly and sufficiently heavily to maintain vigorous pastures, manuka can readily be controlled. This is demonstrated on the dairy and fat lamb farms of the country, which make up the major portion of the manuka-free area of some $2 \frac{1}{2}$ million acres. This country uses by far the greatest proportion of the fertilisers at present available to the farmers. It is expected that the further development of regular topdressing on our hill country will assist materially in the control of manuka, but the regular topdressing of some 6 million acres of hill country in this southern half of the North Island, at a rate sufficient to maintain pastures capable at all times of resisting the invasion of manuka, is hardly a practical proposition, at least for a long time to come. In the meantime the only practical way the hill country man has found of controlling manuka is to cut it regularly, burn where it is thick enough after cutting, and resow such areas.

In some lower rainfall districts cutting is required every 10 years or so, but over most of the hill country with rainfalls upwards of 40in. cutting is necessary every 5 to 8 years.

Costs of cutting vary to-day from $£ 3$ up to $£ 5$ or $£ 6$ per acre and with grass seed costs added farmers are spending an average of $15 /$ - to f.1 or more per acre of their holdings annually in an endeavour to keep ahead of the encroachment of manuka. Labour for manuka cutting, on the ever-increasing area over which this plant is making its appearance, is becoming more and more difficult to secure and in recent years considerable areas of hill country have gone out of production, with the prospect of further and more rapid deterioration in the position, despite the developments in hill country topdressing. While the sandstone soils and pumice-covered soils have in the past been most subject to aggressive manuka invasion, it is very evident that vast areas of the more fertile mudstone, papa, and even limestone hill country are reaching the stage when manuka invasion of these hitherto fairly clean grasslands is becoming more apparent every year.

\section{The Advent of the Mealy Bug}

The mealy bug was first introduced in 1947 on to a 13,000 -acre hill country property some 30 miles inland from Wairoa, where, despite the annual expenditure of thousands of pounds in manuka cutting, the weed had got away over large areas and was steadily encroaching on more and more pasture land. This is steep mudstone country with, however, a fairly deep pumice topsoil over the easier slopes and flat tops. The bug was also established about the same time on another big property at Tangoio, north of Napier. Here again the àggressiveness of the manuka was due to the pumice covering of much of the country.

From a slow beginning the spread of the mealy bug in the Wairoa County, in northern Hawke's Bay, and in Cook and Waikohu Counties in Poverty Bay during the past 3 years has been nothing short of spectacular. A survey of the incidence of scale insects in manuka and kanuka carried out throughout the country in 1949 showed that at Tangoio and Waihi Station, the sites of the first establishment of Eriococcus, this insect had spread into manuka over an area of a few acres. A survey carried out by local instructors in the spring of 1951 showed that the insect was by then to be found everywhere over an area estimated at 350,000 acres. A recent survey this winter shows that the area of infestation now covers upwards of 1 million acres and that whereas in the 1951 survey there were only scattered areas where every manuka plant was affected, to-day there are literally hundreds of thousands of acres from Tangoio through Tutira over the whole of Wairoa County and the greater portion of Cook and Waikohu Counties where almost every manuka plant young or old is so heavily 
infested that death of all plants is certain. This remarkable spread of the insect has been due no doubt to the favourable climatic conditions and also to a large extent to the activities of farmers in taking infested material from one place to another.

That climatic conditions affect the virulence and rate of spread of the insect is shown by the fact that the over-all coverage of young and old manuka has been much more rapid and effective in coastal areas than in inland higher rainfall but colder districts. Here for a start the spread was erratic, older plants being attacked first, with odd plants apparently resistant to the insect attack. Recently, however, this haphazard spread has changed to a complete coverage of all plants, including seedlings, even in the inland areas up to 40 miles from the coast.

Farmers from the northern Poverty Bay counties, central and southern Hawke's Bay, and the Wairarapa, hearing of the progress of the mealy bug in Wairoa County, visited the area and, seeing the possibilities of the insect in manuka control, took home with them car and truck loads of material to start the good work in their own country.

Early establishments of the insect from material from the South Island and from Wairoa were reported before 1949 from North Taranaki, Eltham, Raetihi, and elsewhere. During the last 2 seasons a great deal of material has been taken from one part of the country to another and recent reports indicate that the insect is now well established throughout Hawke's Bay, in the Wairarapa, in the upper Manawatu, Wanganui, and Waitotara, and in the inland counties of Taranaki. It is expected that, judged on the experience farther north, it will be from 4 to 5 years before manuka throughout Hawke's Bay and the Wairarapa is on the way out. Though the bug was well established at Raetihi in 1947 and at Okoke in North Taranaki in 1948, its spread here has been, so far, much slower than in Wairoa County. Several hundred acres of manuka, however, are now showing the effects of the insect attack, but the vigorous piants of these high rainfall areas appear to be more resistant.

The insect, from establishments in the upper Manawatu in 1948 and 1949 , is now starting to make real progress, and though the spread is not likely to be as spectacular as in east coast districts, it looks as though it will be no less effective in controlling manuka at all stages of growth.

\section{Efiects of Manuka Blight}

There can be no doubt about the fact that the mealy bug kills manuka nor that when well established it starts on seedling manuka before the plants have developed sufficiently to harm pastures or compete with other growth.

Close observation and investigation of several claims that the mealy bug was attacking and destroying other plants have shown that no other plant, native or otherwise, with the one exception of kanuka or white manuka (Leptospermum ericoides), has been attacked. Kanuka, though attacked, has shown with few exceptions no ill effects and has continued to stand fresh and green among masses of blackened dead and dying red manuka.

It was thought by some that the killing off of thickets of manuka, particularly where this plant has been in occupation of the land for upwards of 25 to 30 years, would result in the land being left bare and therefore subject to excessive water run-off and sheet erosion. This is very definitely not the case. Observations over the million acres of mealy bug infested country on the east coast during the past 4 to 5 years, covering many variations of soil, climatic, and topographic conditions, have shown that the development of an effective ground cover is remarkably quick; so quick 
and effective, in fact, under all the varied conditions observed, that it can be stated emphatically that within weeks after the first effects of the insect attack are observed, the ground cover against erosion and water run-off is much better than it was under the thriving manuka.

Where the manuka has suppressed pastures and has been in occupation of the land as a dense cover for up to 15 to 20 years there is a rapid development of ground cover as the light gets in and long before the manuka is dead and brittle. This ground cover consists of such native grasses as microelena, danthonia, and the like, as well as browntop, sweet vernal, Yorkshire fog, cocksfoot, Poa pratensis, and various weeds including catsear, hawkbit, and fleabane. Where the manuka has taken over from gorse or blackberry these reappear rapidly with the other species. On unoccupied land or land that has been abandoned to manuka for upwards of 20 years the effect of the mealy bug attack on letting in the light is an equally rapid development of a new and effective ground cover. The major plant in this case, on practically all the country observed, has been bracken fern. It is considered that this would also occur over the great majority of original forested land on pumice country and on most of the other volcanic soils of the North Island. Seedlings of native shrubs and of forest trees have also been observed taking advantage of the opening up of the manuka.

In both cases manuka seedlings were also in evidence, but never in the numbers seen when such stands of manuka are burnt standing; and of course these manuka seedlings are not permitted to make much progress before they are in turn attacked by the mealy bug.

\section{Scattered Manuka No Problem}

It is on the vast areas of scattered manuka, the result of successive years of invasion by seedlings coming into the relatively weak and open turf of hill country, or on poorer low lands, that the mealy bug is doing, and is likely to do, its best and most effective work. To see over thousands of acres of country on which manuka cutting has had to be a regular practice to keep it clean every manuka plant either dead or dying, and seedlings attacked before they have time to do any damage, is something for any hill country man, or a man on lowland country for that matter who is on manuka infested country, to get enthusiastic about. The manuka is killed, his country is free of the pest, his pastures take over from the manuka, and he does not have to do anything at all about it, but just look on.

\section{Follow-up of Destruction of Dense Manuka}

The real problem from the farmer's point of view is whether he can take advantage of the wholesale killing off of dense manuka where it has previously beaten him. To do this he has to get in early, before the natural regeneration of the ground cover already referred to gets too far advanced. The Department of Agriculture has under way several trials in the Wairoa County in connection with this problem the results of which should be of assistance to farmers. It is a difficult problem because of the rapidity of development of a new ground cover from species of grasses, weeds, and other plants not the best for grazing purposes, and also because the tough top growth of the manuka continues to prevent access to areas by stock, including cattle, for several years after the light is let in through the death and fall of the leaves.

The trials aim at the establishment of better grasses at quite an early stage of the attack with and without fertilisers, to see if any better grasses and clovers can be established and, by reseeding, in the absence of stock, during the period the manuka takes to become dead and brittle, survive to take a place in the new pasture. 
Such plants as Lotus major, cocksfoot, and perhaps some of the other grasses and clovers may be able to do this.

The trials were sown with great difficulty under the manuka, but the seeding and topdressing of extensive areas would have to be done from the air. The possibilities of clearing up the top hamper of dead and dying manuka and the first ground cover by fire are also to be explored, though it is recognised that difficulty in controlling such fires would be a problem as well as the possibility of a dense regrowth of seedling manuka.

\section{The Erosion Problem}

Agriculturists and farmers are not unmindful of the erosion problem connected with the wholesale destruction of manuka. They believe, however, as the result of their observations that the removal of manuka, slowly though effectively as is the case with the mealy bug attack, will not leave the ground bare, and that pasture, even grazed pasture, is as effective in water run-off control and the prevention of excessive surface erosion as manuka. They believe also that a plant like bracken fern that will surely succeed manuka on most unfarmed country is a far better soil conservation plant than manuka ever was. Manuka is considered to be the least effective of any native plant because of the hard, comparatively bare ground beneath $i t$, and the shallow rooting system. Bracken fern on unfarmed land will give way more rapidly to deeper and stronger rooting native shrubs, other than manuka, if the manuka continues to be suppressed by the mealy bug; and these native shrubs - the coprosmas, pittosporums, olearias, and so forth - will in turn give way to larger forest species.

Thus it is believed that the erosion and reafforestation problems are not likely to be of such importance as some have claimed. The farmer can control bracken fern relatively easily. He is not afraid of it, but he does not approve of being asked to continue his, in many cases, very expensive and losing battle against manuka.

\section{Safeguards}

The agriculturist knows that there will always be manuka, that no insect will completely eradicate it, and that for very many years to come manuka will continue to regenerate from seed in the ground over many millions of acres of this country. The agriculturist knows, further, that if at any time it is considered, because of some unforeseen circumstances, that the continued destruction of red manuka is undesirable, it should be possible to find and introduce a parasite to control the mealy bug.

This has been possible with the oak tree scale, the blue gum scale, and a number of other scale insects attacking and able to kill fruit and citrus trees were they not controlled by parasites.

The mealy bug Eriococcus is attacked by several parasites, but none of these is really effective in its control. The entomologist, if he set out to do so, could no doubt find and introduce an efficient parasite, as he has for instance in the case of the white butterfly and the diamond-backed moth.

\section{Conclusion}

1. The agriculturist is with the farmer in his desire to make the fullest use possible of the mealy bug Eriococcus in the control of manuka, because of the serious nature of the infestation of farming lands by this weed.

2. The agriculturist considers that the wholesale destruction of manuka will not result in the development of serious and widespread problems of erosion and excessive run-off of water, because there is ample evidence that the killing off of manuka results in an even better ground cover than that given by the manuka. 
3. The agriculturist considers that the increasing loss to the country of grazing land going under manuka because of the inability of the farmer to face the cost or provide the labour to keep this plant in control. and the prospect of a continuing annual expenditure of vast sums in the endeavour to keep land free from manuka are of such moment that these considerations outweigh any arguments that can be brought forward against the use of the mealy bug Eriococcus in the control of this plant

4. The agriculturist believes as the result of close observation that in so far as the North Island is concerned the mealy bug, if left unparasitised, is capable of effectively destroying and controlling manuka throughout the country and that such control would be very much to the advantage of the farming community and to the country as a whole.

\section{DISCUSSION}

Q. If infested manuka is burnt, is the meaiy bug wiped right out, or do sufficient insects survive the fire to carry on the infestation?

A. (Hoy): I have no direct evidence of the effect of fire, but as the insect shelters under the manuka bark, I do not think it would survive a hot fire.

Q. What does Mr. Hoy mean by calling Eriococcus a "new" species?

A. There is no record of it in overseas literature, but I think it possible that it is known overseas. A paper is in print in New Zealand giving it a name.

Q. As the mealy bug is probably introduced, is it not possible that we already have parasites here that will control it?

A. (Hoy): There is a possibility that its parasites are already in New Zealand and if so a parasite complex should build up in time. However, the infestations are already so widespread that there would need to be a tremendous parasite build-up to have any major effect in preserving manuka.

Q. Has there been a complete, exhaustive survey made of the incidence of the blight in New Zealand?

A. (Saxby): There has been no detailed survey made recently, but all known infestations have been recorded.

Q. Can stock carry the insect in the crawler stage?

A. (Hoy): This has not been conclusively demonstrated, but it appears quite practicable. There are millions of crawlers on an infected bush.

Q. I should like to ask Mr. Gardiner why, on the property he mentioned, he advocated surface sowing clover only and not grass?

A. (Gardiner): We did carry out a trial some years ago with the sowing of clovers and English grasses from the air. The clovers established well, but the English grasses never established. We now believe in sowing clover and then sowing the grass 2 or 3 years later. At present we are running nothing but cattle on this property.

Q. Are there individual manuka bushes which are resistant?

A. (Gardiner): Not in my experience. Manuka appears to be completely killed.

Q. Of the land that is affected with manuka blight, how much is going into pasture and how much is reverting to gorse, blackberry, and fern?

A. (Hoy): Along the foothill country in Geraldine County the land is usually reverting to gorse and bracken.

(Gardiner): This is not the case in North Canterbury. Most of the areas won from manuka are being oversown with pasture species with very good results. 
Q. Mr. Hoy mentioned that the mealy bug could be killed with insecticides. What would this cost on a large scale?

A. Using insecticides on a large scale would be quite impracticable. To kill all the mealy bugs it is necessary to spray the bush from all sides. Aerial spraying would be ineffective, as it only gets a cover of the top canopy.

Q. Is there any chance of natural resistance to blight building up in manuka and kanuka?

A. (Hoy): Kanuka stands the blight fairly well, though in high concentrations some plants are killed. At Maronan in a mixed stand the manuka is dying out and the kanuka spreading. There is no sign of resistance building up in young regrowth manuka in infested areas. The young manuka succumbs very quickly.

(Hamblyn): Kanuka is taking over from manuka on the east coast.

Q. Has Mr. Campbell any plans of what to do with the unfarmable country if the manuka blight does spread there?

A. Manuka is a hardy plant that has been here for millions of years, and personally I do not imagine it will go out as easily as some people think. As for the question of plants which will replace manuka, on much of the country manuka will have to be replaced either by grass, maintained by costly farming methods, or by plantations, which will mean costly tree planting.

Q. I think manuka is a symptom of certain poor farming conditions. Mr. Gardiner has seen topdressing areas cleared by the blight with seed and fertiliser. If he had put the seed and fertiliser on for a start, would the manuka have got away in the first place?

A. (Gardiner): On the property I mentioned there has always been manuka in my experience, but in recent years it was increasing markedly. Only aerial topdressing has made application of fertilisers passible on this country, but I think even with early topdressing the manuka would still have spread. Even when I was using a lot of cattle the manuka kept creeping in. Now I am carrying an increased number of sheep and cattle due to manuka blight.

(Hamblyn): A point we must not overlook is that the firestick has been used much less recently. This is because farmers are aware of the damaging effects of fire on the sward and soil, and also because fire is not an effective counter to manuka. Now, due to the blight, farmers no longer have to resort to fire to open up their land.

\section{Comment:}

(Johnson): May I draw attention to the possible effect of manuka blight on the beekeeping industry. Manuka is a prolific yielder of nectar and beekeepers make a limited use of it for bee feed. The honey is very sticky and cannot be extracted by ordinary means. Its colour is dark and the flavour is strong. Manuka is a low-grade honey which has a very limited market.

Much of the inland hill country of the North Island is more suitable for beekeeping than the open, windswept plains, but it is unprofitable because of manuka. Bees will fly 5 miles over clover pasture to get manuka. If the manuka were destroyed, we could expect commercial beekeepers to move in to these areas.

Clovers in the area would get better pollination service, resulting in the setting of more seed, which would be distributed by stock.

These conditions would apply to a great part of the North Island and it is possible that with the near eradication of manuka our better-quality honeys in the North Island could be stepped up by 1000 tons annually. 